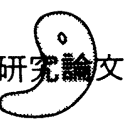

\title{
NC 命令補正方式による高精度旋削加工*
}

\section{一一簡易加工誤差予測曲線とそのデータベースの利用——}

\author{
浅尾 晃 通** 坂 本 正 史** 水垣 善 夫**
}

Fine Precision Turning by Means of Modification of NC Commands

-With Use of a Simplified Predictive Function of

Machining Error and its Data Base-

Teruyuki Asao, Masafumi Sakamoto and Yoshio Mizugaki

This study deals with a compensation system of machining error in turning which has been developed by adopting a simplified predictive function and modifying previously nominal NC commands. The predictive function can be expressed as an exponential curve of which variable is a cutting length. Its coefficients of amplitude and responsibility are determined based on the method of least squares from experimental measurements. They are installed into an auto NC programming tool in the form of a data base of predictive functions. The nominal depth of cut in an $\mathrm{NC}$ command is modified to be reduced by the motion resolution of the cutting tool post at each position of cutting length where the machining error is estimated to exceed the motion resolution. Through the experiments the machining accuracy is achieved within few $\mu \mathrm{m}$ in diameter. The experimental results are illustrated and the conclusions are briefly mentioned.

Key words : precision turning, machining error, modification of NC commands, simplified predictive function, data base

\section{1.はじめに}

超精密加工の進歩は著しく，サブミクロンあるいは ナノメータオーダの旋削が再現性よく行えるよらな超 精密旋盤が出現している. しかし，このような工作機 械は工具（ダイヤモンド），工作物（アルミニウムや 無酸素銅）共に特殊であり一般の機械加工，特に鉄鋼 材の旋削加工では 20 30 $\mu \mathrm{m}$ 程度の加工誤差は避け られず，それ以上の精度を確保しょうとする場合は仕 上加工として切削後研削仕上をしているのが普通であ る. 高能率, 高精度加工を要求される今日, 一般の機 械加工の加工精度と超精密加工の加工精度の間を埋め る努力が早急にされなければならない，市販の旋盤を 用いて，旋削のみで鉄鋼材の加工精度を容易にミク口 ンあるいはサブミクロンオーダにすることができれ ば，使用工作機械が減り，加工工程も少なくなるなど 実用的には大変有用である.

近年, 最小設定単位 $1 \mu \mathrm{m}$ （半径指定 $0.5 \mu \mathrm{m}$ ) の

* 原稿受付 平成 2 年 12 月 7 日. 1989 年度精密工学会春季 大会学術講演会 (平成元年 3 月 22 日) 括よび 1990 年度精 密工学会春季大会学術講演会 (平成 2 年 3 月 30 日) にて 発表

** 正 会 員 九州工業大学 (北九州市戸畑区仙水町 1-1)
$\mathrm{CNC}$ 旋盤が市販され，広く用いられている.しかし， その高分解能が十分に生かされた加工が行われている とはいえない，本論文は最小設定単位 $1 \mu \mathrm{m}$ の CNC 旋盤を用いてその分解能に近い加工精度を保証する予 測制御方法とその実験結果について述べたものであ る.

\section{2. 精度向上 法}

旋盤の最小設定量をいくら小さくしても，バイトが 正しく送られなかったり，切れ刃の付着物や逃げなど によって正しく切削が行われないと, 精度の高い加工 は行えないし, 補正切削によって精度を向上させるこ とも不可能である. 従って，まず次のような点につい て検討する必要がある。

（a）バイトを最小設定単位ずつ動かしたときどの ような切削が行われるか.

（b）除去可能な最小切取り厚さ，粗さ等をどの程 度小さくできるか.

超精密旋削に括いて，（a）に対しては静圧案内，静 圧送り等を用いて微小送りを可能にしている.（b）の 問題に対しては切削系の㓮性を高くし，切れ刃ェッジ のシャープなダイヤモンドバイトを用い，アルミニウ 
ム合金や無酸素銅等の超精密切削材料を軽切削するこ とによって解決している.

市販の CNC 旋盤に汎用のバイトを用いた場合で も, 上記の (a), (b) について問題が無いか, あるい はこの問題が解決されて, 最小設定単位量の切込みが 可能になれば，規則性のある加工誤差を補正すること ができる，例えば，旋削した加工物の形状を機上で計 測したり，あるいはなんらかの方法で加工誤差に相当 する量だけ NC 命令の工具経路を修正しながら補正 旋削すればより精度の高い部品を製作することがで きる。

筆者らは，最小設定単位量が $10 \mu \mathrm{m}$ の NC 旋盤を 用いて誤差に相当する量だけ修正された NC 命令に よって，加工精度を改善し得ることを示しだ”. ま た, 更に, 積層型圧電素子をバイトホルダ内に組み込 んだ補正装置を試作し，NC 装置の最小設定単位量以 下の加工精度に仕上げられることを確認した2．

加工中に工作物の寸法を測りながら補正を行う フィードバック方式は, 切りくずや, 切削液の雾囲気 中におけるセンサの精度や，そのデータを解析するた めのハードウェアの信頼性や処理能力に問題がある.

本研究では切削中にはセンサを用いない方法を考学 た. 加工誤差の補正方法としては次のような方法が考 えられる。

（I）計算機内に加工誤差モデルを作り，このモデ ルによって時々刻々誤差を予測し，実時間で補正 された NC 命令を用いて旋削する.

（II）種々の工具や被削材に対して切削条件を変え た実験を行い，そのときに生じる加工誤差をデー タベースとして計算機内に蓄えて扣き，このデー タを用いて誤差を予測し，NC 命令を修正して旋 削する。

（III）加工誤差を加工機上で簡単に自動測定でき るシステムを作り，試し切削あるいは適当な間隔 でサンプリングした工作物の形状精度を計測し， その誤差を知り NC 命令を補正する方法.

（I）の方法が理想であるが，現時点での有限要素法 等を利用した加工誤差モデルは切削抵抗や切削熱の算 出に拈いて不確定要素が多く，その表現は非常に複雑 である．生産量が多ければ (III)の方法でもよいが, 単品あるいは少量生産の場合は不都合である.

本研究では，（I）の方法をめざしながら，（III）の方 法により（II）のデータを集める方法で研究した。

\section{3. 実験方法及び装置}

切削実験は工作物の曲げ変形が起こらないよう L/
R 0.2

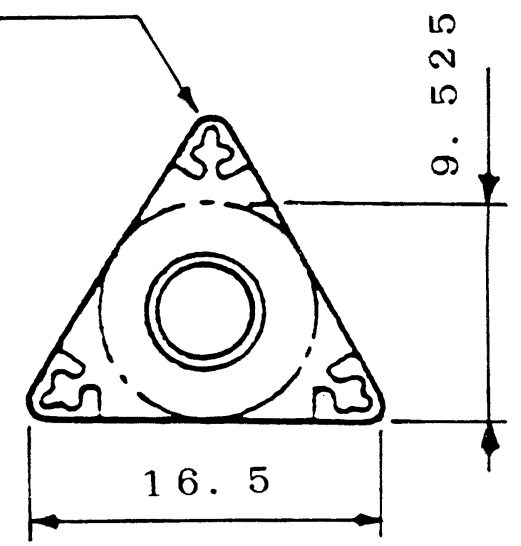

Fig. 1 Throw away tip with chip-breaker

$D$ を 3 程度にとるため, 被削材を $\phi 60 \times 180$ の炭素 鋼（S 35 C）とし，長手方向の $120 \mathrm{~mm}$ を 1 回の切削 とした. 工具は, 汎用の精密加工用スローアウェイ チップを使った. チップは図 1 に示すよらな全周溝型 チップブレーカをもち, ノーズ半径 $0.2 \mathrm{~mm}$ である. 工具形状は $-6^{\circ},-5^{\circ}, 6^{\circ}, 5^{\circ}, 15^{\circ} ; 93^{\circ}$ である.

実験に用いたシステムは 16 ビットのパーソナルコ ンピュータを中心に $\mathrm{I} / \mathrm{O}$ インタフェースと CNC 旋盤 より構成される. CNC 旋盤は瀧澤鐵工所製 TC-2 で ある. $1 \mu \mathrm{m}$ の最小設定単位を持つ $\mathrm{NC}$ 装置は FANUC 社 3 T で, RS-232 C 通信回線を介して NC 命令が転送される.

加工誤差のデータ収集のため，切削後工作物を チャックに取り付けたままの状態で, 刃物台に電気、 イクロメータを取り付け，仕上の工具軌跡と同じ経路 を動かす．その時の電気マイクロメータの出力電圧を 12 ビットの A/D 変換器を用い, データをパーソナル コンピュータ内に取り込み，各位置での加工誤差を相 対値として得られるよらにした。 これら測定用 $\mathrm{NC}$

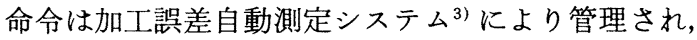
測定間隔, 電気マイクロメータの形状（本体の直径, 先端半径）は任意に選択することが可能である. 本実 験では, 本体直径 $\phi 8$, 先端半径 $1.5 \mathrm{~mm}$, 測定間隔 $0.5 \mathrm{~mm}$ で行った. 工作機械の熱変形による誤差はこ の方法では測定できないが，切削後機械，工作物が十 分に冷却された状態で測定を行った。

\section{4. 精度制御の方法と $\mathrm{NC}$ 装置の 切込み方向信頼性}

旋削加工時の一般的な加工誤差を図 2 に示すが，図 より加工が進行するに従って工作物の直径が減少する 

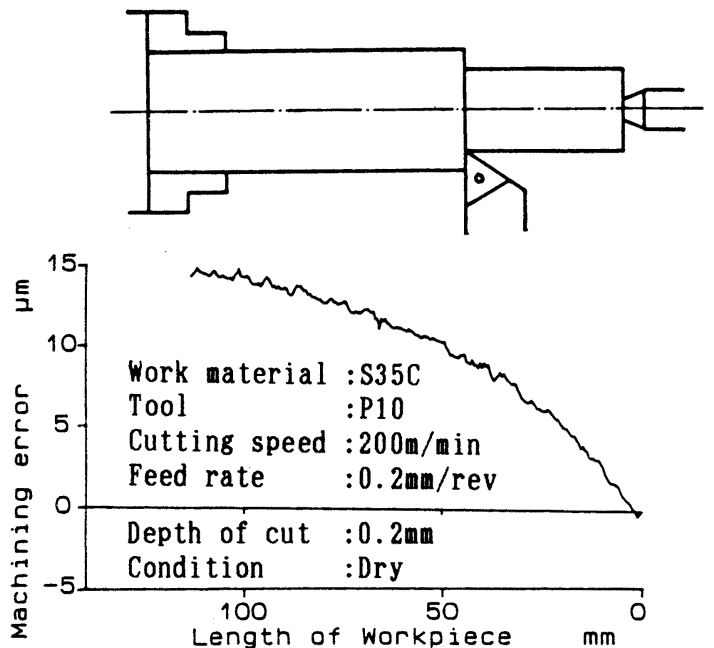

Fig. 2 Machining error

傾向がみられる. 加工誤差は，切込み方向 ( $X$ 方向) に起こるので，これを除去するには，削り過ぎた分ま たは削り足りない分だけ工具を $X$ 方向に移動させれ ばよい.パーソナルュンピュータ内で加工誤差の関数 近似式を作り，各位置での加工誤差を計算し，それが 1 パルス当たりの最小設定単位 $\Delta X$ （直径方向）を越 えるごとに工具を $\Delta X$ だけ前進または後退するよう にNC 命令をあらかじめ修正して扣き，その NC 命 令を利用して加工する.

この加工がより正しく行えるかどらかは，切削中に 1 パルスずつ刃物台をX軸方向に移動させた場合, ボールねじのスティックスリップやバックラッシ等の 影響が無く，確実に1パルス分だけ刃物台（工具）が 駆動するかどらか，また，その駆動分だけ切削されて いるかどらかにかかっている. それを確認するため に，以下のよらな NC 命令を作り切削実験を行った.

（I） 円筒切削に拈いて，七ンタ側から切込み 0.1 $\mathrm{mm}$ で $10 \mathrm{~mm}$ までをストレートに切削し，そこ から $1 \mathrm{~mm}$ 進むごとに工具を 1 パルスつまり直径 方向で $1 \mu \mathrm{m}$ だけ $X$ 方向に切り达む. これを 17 回繰り返し，さらに $1 \mathrm{~mm}$ 進むごとに 1 パルスず つ工具を引く.これを 17 回繰り返し， $30 \mathrm{~mm}$ ス トレートに切削する. その工具軌跡と測定值を図 3 (I) に示す.

（II）同様に円筒切削に打いて，センタ側から 10 $\mathrm{mm}$ までをストレートに切削し，そこから $1 \mathrm{~mm}$ 進むごとに工具を 1 パルスつまり直径方向で 1 $\mu \mathrm{m}$ だけ $X$ 方向に引く.これを 17 回繰り返し， さらに $1 \mathrm{~mm}$ 進むごとに 1 パルスずつ工具を切り 込み,これを 17 回繰り返し，30 mm ストレート

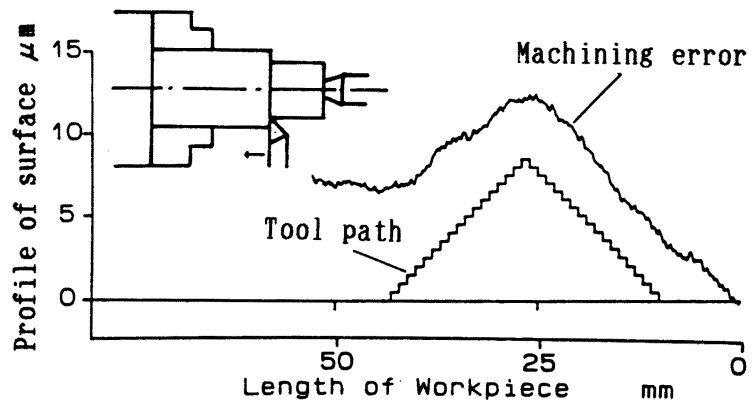

( I In case of feed in a cap

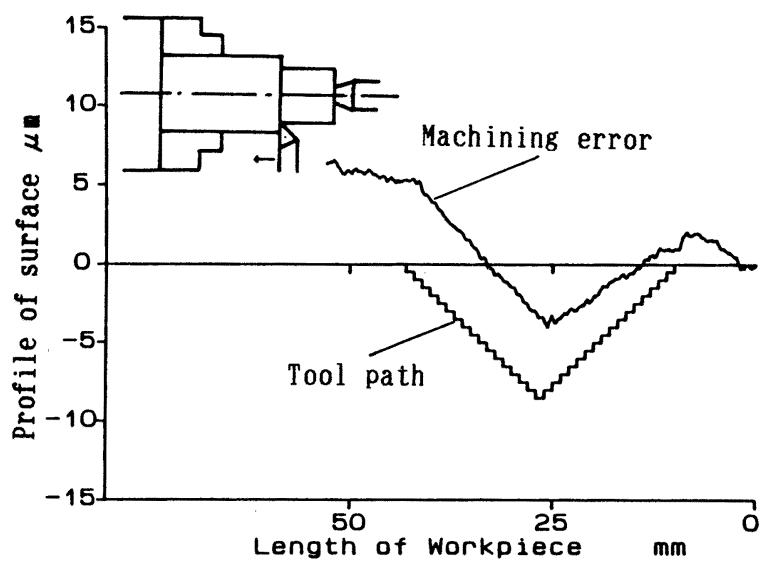

(II) In case of feed in a cup

Work material :S35C

Tool : 10

Cutting speed :200m/min

Feed rate $: 0.1 \mathrm{~mm} / \mathrm{rev}$

Depth of cut :0.1mm

Condition :Dry

Fig. 3 Traveling tool path and generated profile of workpiece

に切削する. その工具軌跡と測定値を図 3 (II) に 示す.

図 3 (I) では切削開始から $10 \mathrm{~mm}$ 以降刃物台を切 り込んだ時点から急激に加工誤差が増し，27 mm か らはまた減少している.図 3 (II) では逆に $10 \mathrm{~mm}$ 以 降刃物台を引いた時点から加工誤差が減少し， $27 \mathrm{~mm}$ の時点から増加し，44 $\mathrm{mm}$ からはまた通常の加工誤 差の状況に戻っている. 加工誤差のグラフは工具経路 に加工誤差を上乗せしたものになっており，それぞれ の工具経路と加工誤差との差は図 2 と一致している.

つまり， CNC 旋盤の $X$ 軸のバックラッシ補正の効 果もあり最小設定単位の指令に対して, 刃物台が移動 し, 市販のノーズ半径 $0.2 \mathrm{~mm}$ のチップでも最小設定 単位の值まで実際に切削されていることが確認され る. 


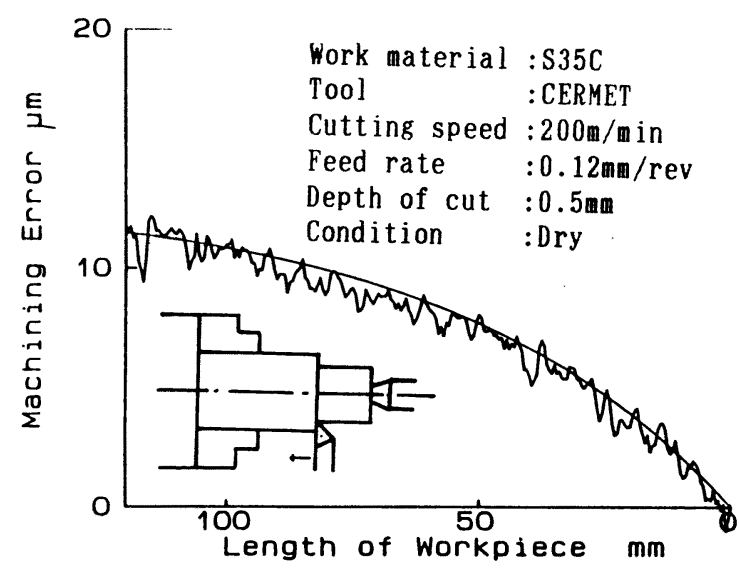

(a)

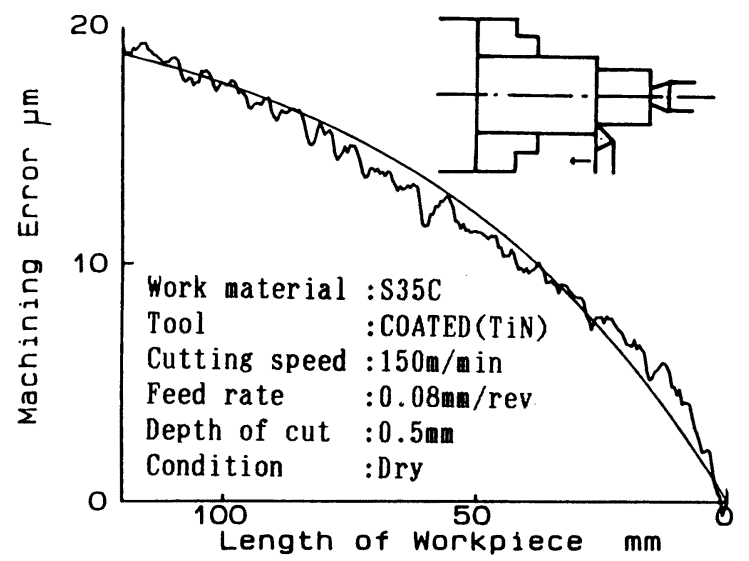

(b)

Fig. 4 Machining error and predictive function

\section{5. 加工誤差の関数近似}

計算機内に蓄積された加工誤差のデータを基に加工 誤差モデルを構築する.ここでは切削距離を变数 $X$ とし, 切削条件は定数化 $\left(C_{1}, C_{2}\right)$ した加工誤差モデ ル関数 $f(X)$ を考光る.

$$
f(X)=C_{1}\left\{1-\exp \left(-C_{2} \bullet X\right)\right\}
$$

・この関数は加工誤差の主要因が工具の熱膨張による ものと仮定したときの加工誤差関数であり, 最小設定 単位が $10 \mu \mathrm{m}$ の $\mathrm{NC}$ 旋盤の加工に括いて評価に利用 した関数である ${ }^{3)}$. 今回は最小設定単位が $1 \mu \mathrm{m}$ の CNC 旋盤に技いてもその関数が適応できるか考慮し たところ，図4 に示すように良く一致している.

式中の $C_{1}, C_{2}$ は工具, 切削条件の組合せにより決 定される係数である. 実際には, 前述の加工誤差自動 測定システムを用いて測定された加工誤差データから 最小二乗法により計算し, 切削不能になるまでの各値
Table 1 Database of $C_{1}, C_{2}$ with cutting conditions

\begin{tabular}{|c|c|c|c|c|c|}
\hline Tool & $\mathrm{m} / \mathrm{min}$ & $\begin{array}{c}a \\
\mathrm{~mm}\end{array}$ & $\underset{\mathrm{mm} / \mathrm{rev}}{f}$ & $C_{1}$ & $\begin{array}{c}C_{2} \\
\times 10^{-5}\end{array}$ \\
\hline \multirow{4}{*}{ Carbide } & \multirow{2}{*}{100} & \multirow{2}{*}{0.5} & 0.08 & 11.9 & 1.4 \\
\hline & & & 0.12 & 11.9 & 1.9 \\
\hline & \multirow{2}{*}{200} & \multirow{2}{*}{0.5} & 0.08 & 7.1 & 1.8 \\
\hline & & & 0.12 & 9.5 & 2.9 \\
\hline \multirow{12}{*}{$\begin{array}{l}\text { Coated } \\
\text { (TiN) }\end{array}$} & \multirow{6}{*}{100} & \multirow{2}{*}{0.3} & 0.10 & 10.2 & 1.9 \\
\hline & & & 0.15 & 10.2 & 3.5 \\
\hline & & \multirow{2}{*}{0.5} & 0.05 & 10.3 & 0.8 \\
\hline & & & 0.12 & 10.5 & 1.8 \\
\hline & & \multirow{2}{*}{0.7} & 0.05 & 10.3 & 0.6 \\
\hline & & & 0.12 & 10.5 & 1.6 \\
\hline & \multirow{6}{*}{150} & \multirow{2}{*}{0.3} & 0.12 & 11.1 & 1.1 \\
\hline & & & 0.15 & 9.2 & 2.2 \\
\hline & & \multirow{2}{*}{0.5} & 0.10 & 11.2 & 1.7 \\
\hline & & & 0.12 & 12.0 & 2.2 \\
\hline & & \multirow{2}{*}{0.7} & 0.05 & 13.0 & 0.4 \\
\hline & & & 0.08 & 12.1 & 0.7 \\
\hline \multirow{12}{*}{ Cermet } & \multirow{6}{*}{150} & \multirow{2}{*}{0.3} & 0.05 & 7.5 & 1.5 \\
\hline & & & 0.08 & 8.6 & 2.0 \\
\hline & & \multirow{2}{*}{0.5} & 0.05 & 6.9 & 0.8 \\
\hline & & & 0.08 & 7.4 & 1.5 \\
\hline & & \multirow{2}{*}{0.7} & 0.10 & 10.4 & 1.8 \\
\hline & & & 0.12 & 9.5 & 3.1 \\
\hline & \multirow{6}{*}{200} & \multirow{2}{*}{0.3} & 0.05 & 8.0 & 0.5 \\
\hline & & & 0.08 & 8.1 & 1.1 \\
\hline & & \multirow{2}{*}{0.5} & 0.10 & 8.5 & 1.7 \\
\hline & & & 0.12 & 9.5 & 2.1 \\
\hline & & \multirow{2}{*}{0.7} & 0.10 & 9.5 & 1.7 \\
\hline & & & 0.12 & 9.8 & 3.1 \\
\hline
\end{tabular}

$v$; cutting speed, $a$; depth of cut, $f$; feed per revolution
の平均値をとった． $C_{1}$ は主に加工誤差の絶対量を, $C_{2}$ は主にその傾き（応答）を表す係数である. 各種 切削条件による $C_{1}, C_{2}$ の值を求めると表 1 のように なる. 図 5 に切削距離（切削回数）に対する $C_{1}$ の值 を示すが， $3600 \mathrm{~m}$ （8 回）以降の切削は切りくずが 工作物に巻き付き切削が不可能になった. 同時に工作 物の表面粗さを測定したものを図 6 に示すが，その変 化の様子は $C_{1}$ のグラフと一致している. 図 7 には切 削距離がそれぞれ $450 \mathrm{~m}$ (1 回), $1360 \mathrm{~m}$ (3回), $3600 \mathrm{~m}$ (8 回) のときのチップ先端の写真を示すが, コーティング層が剥離すると急激にフランク摩耗やク レータ摩耗が進行している様子がわかる．これらの結 果から $C_{1}, C_{2}$ は精密加工の範囲では工具, 被削材, 切削条件が等しければほぼ一定の值を示すことがわか る.これらのことから，加工誤差近似関数表現を用い 


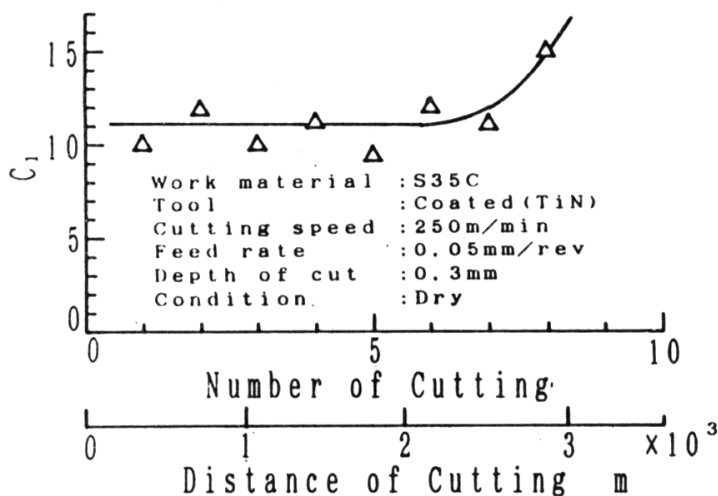

Fig. 5 Variation of $C_{1}$ with distance of cutting

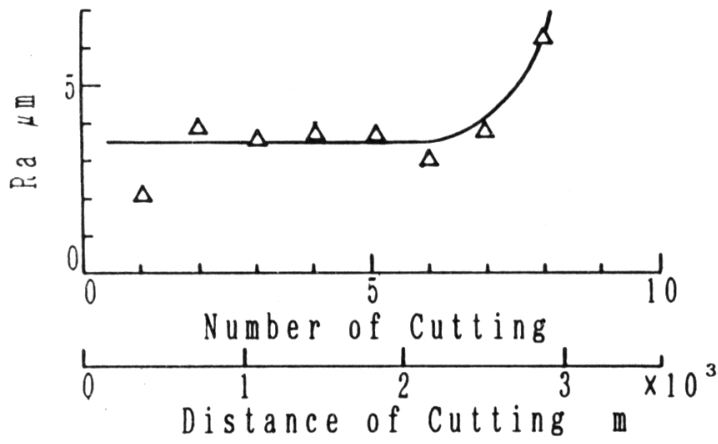

Fig. 6 Variation of surface roughness with distance of cutting

て加工誤差補正が行えることがわかる.

\section{6. 外周旋削の加工誤差と誤差補正実験}

本システムを旋削加工の最も一般的な円筒形状工 作物の外周切削について適用した例を図 8 (a), (b) に示す.工作物は切削抵抗によるたわみの影響を無く すために $L / D$ を 3 以内に設定した。 CNC 旋盤は外 気温度の影響を受けない場所に設置した。あた，あら かじめ 20 分のならし運転後切削を行い加工の履歴に は依存しないことも確認した。通常の切削では, 10

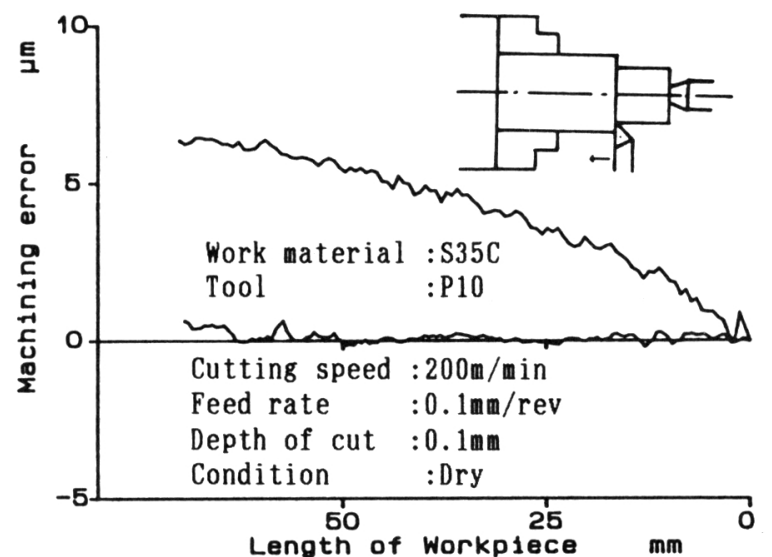

(a)

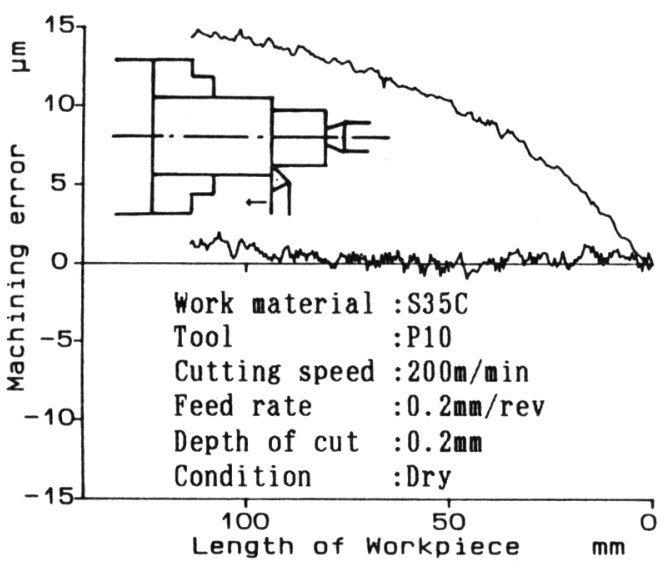

(b)

Fig. 8 Improvement of machining error by modified $\mathrm{NC}$ data

$\mu \mathrm{m}, 15 \mu \mathrm{m}$ の加工誤差がそれぞれ表面粗さ以内であ る $3 \mu \mathrm{m}$ 前後に補正され, 精密加工が行われた様子が 確認できる.

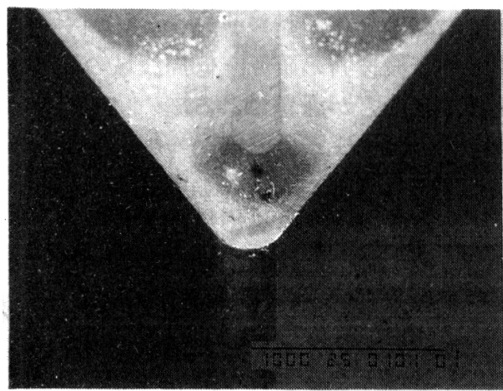

(a) Distance of cutting ; $450 \mathrm{~m}$

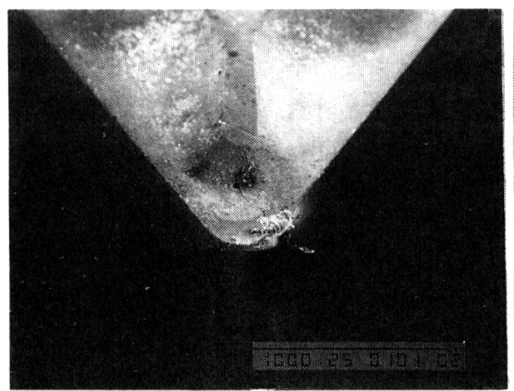

(b) Distance of cutting ; $1360 \mathrm{~m}$

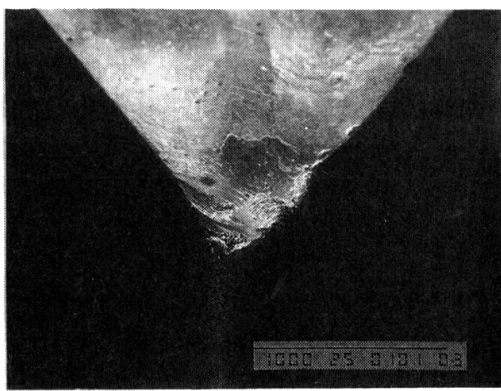

(c) Distance of cutting ; $3600 \mathrm{~m}$

Fig. 7 . Wear of cutting tool due to distance of cutting 


\section{7. 結言}

旋削加工の高精度化を目指すために，CNC 旋盤の 最小設定単位 $(1 \mu \mathrm{m})$ を利用した予測制御方式によ る加工誤差補正を試みた．今回は，基礎実験として円 筒形状工作物の外周旋削に適用し，次の結果を得た。

(1) 旋削加工誤差は, 非常に簡単な加工誤差関数 で表現できることが確認された。

（2） CNC 旋盤に打いて，最小設定単位である 1 $\mu \mathrm{m}$ ごとの指令に対して, 刃物台の駆動，切削共 に確実に行われていることが確認された。

（3）加工誤差データを基に $1 \mu \mathrm{m}$ ごとに修正され た NC 命令により切削し，最大 $15 \mu \mathrm{m}$ あった加 工誤差が $3 \mu \mathrm{m}$ 以内に補正され， $\mathrm{CNC}$ 旋盤の分 解能に近い加工精度に旋削する可能性を示した. 今後は, データベースを自動プログラミングシステ ムに組み込み，一般形状に対応させると共にその形状
データより最適加工条件を考慮した NC 命令を生成 し， CNC 旋盤のもつ高能率化とあわせて高精度化を も実現したい.

本研究の遂行にあたっては，科学研究費（62750115） の補助を受けたこと，ならびに切削実験は東陶機器株 式会社・中山壮一氏，厚木ュニシア株式会社・福田達 也氏にご協力いただいたことを付記し，謝意を表す.

\section{参 考 文 献}

1）竹内芳美，坂本正史，浅尾晃通，井村公二：NC 旋盤の $\mathrm{DNC}$ 化（第 8 報）一工具熱膨張の予測補償，昭和 59 年 度精機学会秋季大会学術講演会講演論文集,（1984） 521.

2）竹内芳美, 坂本正史, 浅尾晃通, 中村 平：玨電素子に よる旋削加工精度制御一一円筒形状工作物について，精 密工学会誌，53，10（1987） 1576 .

3）竹内芳美, 坂本正史, 浅尾晃通, 井村公二：パーソナル コンピュータによる NC 装置の DNC 化（第 3 報）——旋 削加工誤差の自動測定とその評価, 精密工学会誌, 53, 6 (1987) 902.

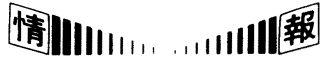

\section{科技庁, AI で非破壊評価研究推進}

科学技術庁は平成 3 年度から 5 年計画で約 30 億円を 投じ，産学官共同体制で高い信頼性が求められている材 料 - 構造物の定量的 - 知能的非破壊評価法の開発に着手 する.これは宇宙や原子力のような安全性が強く求めら れる巨大構造物や, 超精密化しつつある微小機械, エレ クトロニクスで久かせない高度な安全性と信頼性を評価 する手法を開発しようというのがねらいである. 研究対 象は超音波測定技術の高度化とそのデータの処理システ ムが中心である。

これによりマイクロエンジニアリングとミクロエンジ ニアリングに共通する材料評価手法の確立が期待され る.

ところでこの研究に参加するのは, 三菱電機, 新日本 製鉄，三菱総合研究所など民間企業と，科学技術庁の金 属材料技術研究所, 工業技術院の機械技術研究所之計量 研究所, 建設省・土木研究所, 運輸省・船舶技術研究所, 東京大学, 東海大学などで, 産学官共同の研究体制を確 立して科学技術振興調整費の 3 年度新規課題として取り 組む.

材料の非破壊評価法は超高速輸送機, 宇宙構造物, 大 深度地下空間利用などの次世代巨大システムの安全性評 価に不可欠である。 また，微小機械など医療機器や精密 工学での信頼性確保を裏付ける基盤技術でもある.とく
に先進国で進む大型技術から高付加価値技術への移行を 背景に世界的に重視されている.

そのため，すでに米国では全米科学財団 (NSF) や エネルギー省 (DOE) のテコ入れで定量的非破壊評価 法の基礎研究が進んでいる.わが国でも計測や理論面で の研究が始まったが，取組みの遅れが目立つことから関 係する産学官の研究者を結集して組織的な研究に着手す る.

研究内容は，（1）定量的な超音波を使った非破壊計測 技術，（2）超音波を解析するための弾性波動理論による 数学的モデル，(3) データ処理を行う AI (人工知能), （4）共通基盤技術の開発と適用——など，計測技術では 超音波や光音響顕微鏡の高精度化，レーザ超音波計測や マイクロウェーブ電磁超音波技術の研究，低周波域の高 帯域・高感度センサの開発などが課題である.

弾性波動モデルは各種欠陥による散乱波動の解析と画 像処理, 数学モデルの実証など, AI ではニューラル ネットワークやエキスパートシステムとの融合と適用を 研究する．また，基盤技術では欠陥の特徵抽出やプロト タイプの開発，先端材料の定量的・知能的非破壊評価, エレクトロニクス材料の評価システムの開発などに取り 組む。 （服部 敏夫） 